\title{
Anaerobic carboxydotrophic bacteria in geothermal springs identified using stable isotope probing
}

\author{
Allyson L. Brady ${ }^{1+}$, Christine E. Sharp ${ }^{1}$, Stephen E. Grasby ${ }^{2}$ and Peter F. Dunfield ${ }^{1 *}$ \\ ${ }^{1}$ Department of Biological Sciences, University of Calgary, Calgary, AB, Canada, ${ }^{2}$ Geological Survey of Canada, Calgary, AB, \\ Canada
}

OPEN ACCESS

Edited by:

Steffen Kolb,

Friedrich-Schiller-Universität Jena,

Germany

Reviewed by:

Alexander V. Lebedinsky,

Winogradsky Institute of Microbiology,

Russia

Martin Taubert,

Friedrich-Schiller-Universität Jena,

Germany

${ }^{*}$ Correspondence:

Peter F. Dunfield,

Department of Biological Sciences,

University of Calgary, 2500 University

Drive NW, Calgary, AB T2N 1N4,

Canada

pfdunfie@ucalgary.ca

${ }^{\dagger}$ Present Address:

Allyson L. Brady,

School of Geography and Earth

Sciences, McMaster University,

Hamilton, ON, Canada

Specialty section:

This article was submitted to

Terrestrial Microbiology,

a section of the journal

Frontiers in Microbiology

Received: 30 May 2015

Accepted: 17 August 2015

Published: 01 September 2015

Citation:

Brady AL, Sharp CE, Grasby SE and

Dunfield PF (2015) Anaerobic

carboxydotrophic bacteria in

geothermal springs identified using

stable isotope probing.

Front. Microbiol. 6:897.

doi: $10.3389 /$ fmicb.2015.00897
Carbon monoxide $(\mathrm{CO})$ is a potential energy and carbon source for thermophilic bacteria in geothermal environments. Geothermal sites ranging in temperature from 45 to $65^{\circ} \mathrm{C}$ were investigated for the presence and activity of anaerobic CO-oxidizing bacteria. Anaerobic CO oxidation potentials were measured at up to $48.9 \mu$ moles $\mathrm{CO} \mathrm{g}^{-1}$ (wet weight) day ${ }^{-1}$ within five selected sites. Active anaerobic carboxydotrophic bacteria were identified using ${ }^{13} \mathrm{CO}$ DNA stable isotope probing (SIP) combined with pyrosequencing of $16 S$ rRNA genes amplified from labeled DNA. Bacterial communities identified in heavy DNA fractions were predominated by Firmicutes, which comprised up to 95\% of all sequences in ${ }^{13} \mathrm{CO}$ incubations. The predominant bacteria that assimilated ${ }^{13} \mathrm{C}$ derived from CO were closely related (>98\% 16S rRNA gene sequence identity) to genera of known carboxydotrophs including Thermincola, Desulfotomaculum, Thermolithobacter, and Carboxydocella, although a few species with lower similarity to known bacteria were also found that may represent previously unconfirmed CO-oxidizers. While the distribution was variable, many of the same OTUs were identified across sample sites from different temperature regimes. These results show that bacteria capable of using $\mathrm{CO}$ as a carbon source are common in geothermal springs, and that thermophilic carboxydotrophs are probably already quite well known from cultivation studies.

Keywords: carboxydotrophs, stable isotope probing, geothermal, carbon monoxide (CO), thermophile

\section{Introduction}

Carbon monoxide ( $\mathrm{CO})$ is an odorless gas toxic to many animals due to its competitive binding to hemoglobin (Haab, 1990). It has been estimated that about $3.3 \times 10^{9}$ metric tons of CO are released annually to the atmosphere (Conrad, 1996). There are numerous natural biogenic and abiogenic sources of $\mathrm{CO}$. Thermal decomposition and photochemical degradation of organic compounds are important sources of abiotic CO (Sipma et al., 2006). CO is also a component of volcanic emissions, which may contain as much as $1-2 \%$ of CO per volume of total gas (Giggenbach, 1980; Svetlichny et al., 1991a; Sokolova et al., 2009 and references therein). Biogenic CO may also be produced in microbial ecosystems, and net CO production has been reported for marine algae (Conrad, 1988) and hypersaline cyanobacterial mats (Hoehler et al., 2001) during photosynthesis. Sulfate-reducing bacteria (SRB) have also been shown to produce CO during fermentation (Voordouw, 2002). Some microbes growing in high temperature environments are likely capable of growth at low concentrations of CO (Sokolova et al., 2009). It has also been suggested that CO-oxidizing microbes 
may occupy micro-niches in which biogenic CO locally accumulates to high levels (Techtmann et al., 2009).

Microorganisms that have the ability to oxidize $\mathrm{CO}$ are termed "carboxydotrophs" (King and Weber, 2007). A number of aerobic and anaerobic bacteria as well as some anaerobic archaea (e.g., methanogens) are capable of using $\mathrm{CO}$ as a source of energy and/or carbon (e.g., Mörsdorf et al., 1992; Oelgeschläger and Rother, 2008; Sokolova et al., 2009). Carboxydotrophic energy generation employs the enzyme CO dehydrogenase $(\mathrm{CODH})$ that oxidizes $\mathrm{CO}$ to $\mathrm{CO}_{2}$, generating electrons. The aerobic and anaerobic versions of this enzyme differ. Anaerobic CODH in bacteria is encoded by coos genes (Techtmann et al., 2011) and contains nickel in the active site, while aerobic $\mathrm{CODH}$ is encoded by cox genes and contains molybdenum (e.g., Dobbek et al., 2001; King and Weber, 2007). Within the Domain Bacteria, anaerobic carboxydotrophs are typically found within the phylum Firmicutes and some in the class Alphaproteobacteria of the Proteobacteria (see Techtmann et al., 2009). Purple non-sulfur bacteria (i.e., phototrophic Alphaproteobacteria) exist among the known anaerobic $\mathrm{CO}$ oxidizers and were among the first discovered (Uffen, 1981; Kerby et al., 1995). However, an increasing number have been identified that are strictly anaerobic thermophiles belonging to the phylum Firmicutes (e.g., Svetlichny et al., 1991b; Sokolova et al., 2002). Hydrothermal systems have been proposed as early ecosystems supporting chemolithotrophic life, including thermophilic anaerobic bacteria and archaea using $\mathrm{CO}$ as an energy and carbon source (e.g., Cavicchioli, 2002; Wächtershäuser, 2006; King and Weber, 2007). Examples of thermophilic archaea that use CO include Thermococcus sp. NA1, capable of both heterotrophic and carboxydotrophic growth (Lee et al., 2008) and Archaeoglobus fulgidus capable of using CO as an autotrophic growth substrate (Henstra et al., 2007a).

While the anaerobic oxidation of CO may be coupled to a variety of respiratory processes such as sulfate reduction and acetogenesis (Oelgeschläger and Rother, 2008), hydrogenogenic carboxydotrophs make up the majority of thermophilic CO oxidizing microbes that have been identified in geothermal environments (e.g., Svetlichny et al., 1991a,b; Sokolova et al., 2004, 2005; Slepova et al., 2006). These bacteria oxidize CO via the water-gas-shift reaction (Uffen, 1981; Sipma et al., 2006):

$$
\mathrm{CO}+\mathrm{H}_{2} \mathrm{O} \rightarrow \mathrm{CO}_{2}+\mathrm{H}_{2} \quad\left(\Delta \mathrm{G}^{0}=-20 \mathrm{~kJ}\right)
$$

Thermophilic bacteria and archaea with the capacity for hydrogenogenic carboxydotrophy have been isolated from various locations around the world including the Kunashir Island, Russia (Svetlichny et al., 1991a), Kamchatka (Sokolova et al., 2002; Slepova et al., 2006), Yellowstone National Park (Sokolova et al., 2004), and Iceland (Novikov et al., 2011). The isolates share similar ranges of optimal $\mathrm{pH}$ (ca. 6.8-7.0) and temperature (ca. $55-83^{\circ} \mathrm{C}$ ) (see Henstra et al., 2007b; Techtmann et al., 2009) but are phylogenetically divergent (Techtmann et al., 2009). Unlike mesophilic carboxydotrophs, the thermophilic hydrogenogenic species isolated so far do not show growth inhibition by high levels of CO. In fact, most grow under atmospheres of $100 \% \mathrm{CO}$, far above natural CO concentrations in geothermal systems (e.g., Svetlichny et al., 1991a,b).
$\mathrm{CO}$ oxidizing thermophiles are of potential biotechnological interest for the anaerobic fermentation of synthesis gas ("syngas"). Syngas is a product comprised mostly of $\mathrm{H}_{2}, \mathrm{CO}$, and $\mathrm{CO}_{2}$ resulting from the high temperature gasification of waste biomass, into higher-value bioalcohol fuel (Henstra et al., 2007b). As syngas is produced at high temperatures, bacteria from geothermal sites are of particular interest due to the expected high rates of substrate conversion at high temperatures. Characterization of anaerobic CO-oxidizing bacteria in geothermal systems therefore could provide fundamental information about the natural diversity of thermophilic carboxydotrophs available for these biotechnological applications. DNA-Stable Isotope Probing (SIP) is a valuable tool in assessment of functional bacterial groups. It has been used in a variety of environments to identify active consumers of substrates such as methane (He et al., 2012; Sharp et al., 2012, 2014b). There are however some difficulties in applying SIP to identify carboxydotrophs. Firstly, while some carboxydotrophic bacteria directly incorporate CO-carbon into the carboxyl group of acetate via acetyl-CoA synthases (ACSs) using the Wood-Ljungdahl pathway (e.g., Henstra et al., 2007b), others incorporate the $\mathrm{CO}_{2}$ produced from $\mathrm{CO}$ oxidation as the direct source of cellular carbon, using reductive $\mathrm{CO}_{2}$ pathways such as the Calvin-Benson-Bassham (CBB) Cycle, or the reverse tricarboxylic acid (TCA) cycle (Uffen, 1981; Ragsdale, 1991, 2004; Berg, 2011). As such, $\mathrm{CO}_{2}$ present in the atmosphere may be incorporated rather than the $\mathrm{CO}_{2}$ produced directly from the oxidation of $\mathrm{CO}$ diluting the labeling effect. Another issue with CO-SIP is that the products of $\mathrm{CO}$ oxidation, i.e., $\mathrm{H}_{2}$ and $\mathrm{CO}_{2}$, may result in labeling of other autotrophs. Cross-feeding is a caveat in any SIP experiment, but the severity of the crossfeeding, especially via $\mathrm{CO}_{2}$, can often be assessed with controls such as the addition of exogenous ${ }^{12} \mathrm{CO}_{2}$ (e.g., Sharp et al., 2012). CO-SIP will also not detect carboxydoheterotrophs that may oxidize CO but use a different carbon source. Therefore, in this study we assessed the value of CO-SIP to identify anaerobic thermophilic carboxydoautotrophic bacteria in some geothermal springs.

\section{Materials and Methods}

\section{Geothermal Spring Sample Collection}

Five geothermal springs were selected for CO-SIP investigations from among geothermal sites in Western Canada (Grasby et al., 2000; Sharp et al., 2012). Soil or sediment or biomat samples were collected at various times of the year between fall 2010 and fall 2012 into sterile screw-cap tubes (Table 1). Samples were kept cold as soon as possible to minimize changes in the microbial community during transport. Collected material was sub-sampled within approximately 5 days of sampling for DNA extraction, and the remainder was stored at $4^{\circ} \mathrm{C}$ for $1-2 \mathrm{~d}$ prior to incubation studies.

\section{Soil Microcosms and CO Oxidation}

Approximately $2-5 \mathrm{~g}$ of sample material (wet weight) was added to $120-\mathrm{ml}$ serum bottles and crimp-sealed with sterile blue butyl rubber stoppers. An anoxic environment was created by repeated $(3 \times)$ evacuation and refilling with $\mathrm{N}_{2}$ gas. $\mathrm{CO}$ was 
TABLE 1 | Name of geothermal spring, measured in situ $\mathrm{pH}$ and temperature, and anaerobic CO-oxidation potentials for sites included in the current study.

\begin{tabular}{|c|c|c|c|c|c|c|}
\hline Geothermal site & Sample ID & Description & $\begin{array}{c}\text { Environmental } \\
\text { temperature }\left({ }^{\circ} \mathrm{C}\right)\end{array}$ & $\begin{array}{c}\text { Incubation } \\
\text { temperature }\left({ }^{\circ} \mathrm{C}\right)\end{array}$ & pH & 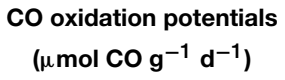 \\
\hline \multirow[t]{3}{*}{ Dewar Creek } & DCm2010 & biomat & 54.9 & 55 & 8.30 & $20.4 \pm 1.8$ \\
\hline & DCmN11 & biomat & 45.0 & 45 & 8.30 & $24.6 \pm 1.1$ \\
\hline & DCs9 & sediment & 64.7 & 65 & 7.94 & $48.9 \pm 5.4$ \\
\hline Lakelse & L3 & organic rich sediment & 45.1 & 55 & 8.27 & $13.6 \pm 2.7$ \\
\hline Grayling River & GR1 & sediment & 56.1 & 55 & 7.02 & $18.6 \pm 4.2$ \\
\hline Liard & Liard2 & biomat & 53.5 & 55 & 6.76 & $30.2 \pm 1.0$ \\
\hline Portage Brûlé & PB1 & biomat & 45.9 & 45 & 6.34 & $35.7 \pm 3.7$ \\
\hline
\end{tabular}

Oxidation potentials represent duplicate incubations and are listed in $\mu \mathrm{mol} \mathrm{CO} \mathrm{g}^{-1}$ (wet weight) $d^{-1}$ with one s.d.

added to final mixing ratios of $5-10 \%$ in the headspace to assess oxidation potential and act as a ${ }^{12} \mathrm{C}$ incubation for stable isotope probing (SIP) experiments. For SIP experiments, labeled gases ${ }^{13} \mathrm{CO}\left(99\right.$ atom $\%{ }^{13} \mathrm{C}$, Sigma Aldrich) and ${ }^{13} \mathrm{CO}_{2}$ (99 atom \% ${ }^{13} \mathrm{C}$, Sigma Aldrich) were used at mixing ratios of $10 \% \mathrm{v} / \mathrm{v}$, both separately and in combination with non-labeled $\mathrm{CO}$ and $\mathrm{CO}_{2}$ gases in different SIP trials. "Control" is used to refer to the un-incubated (i.e., no $\mathrm{CO}$ or $\mathrm{CO}_{2}$ added) environmental samples. Microcosms were incubated at close to environmental temperatures (Table 1). Headspace $\mathrm{CO}$ was monitored at ca. 1d intervals using a Varian 450-Gas Chromatograph equipped with a $0.5-\mathrm{m}$ Hayseep $\mathrm{N}$ and a $1.2-\mathrm{m}$ Mol Sieve $16 \mathrm{X}$ column in series coupled to a Thermal Conductivity Detector (GC/TCD). Potential production of methane was monitored using a GCFlame Ionization Detector (FID). Incubations proceeded until approximately $95-100 \%$ of the added CO had been consumed, typically within a week. Samples were then harvested and frozen immediately at $-85^{\circ} \mathrm{C}$. CO consumption rates were based on duplicates of any sample $\left({ }^{12} \mathrm{CO}\right.$ and ${ }^{13} \mathrm{CO}$ only incubations), while duplicate SIP experiments were performed only in some cases.

\section{DNA Extraction and Density Fractionation}

DNA was extracted from approximately $500 \mathrm{mg}$ of sample using the FastDNA Spin Kit (MP Biomedicals) with the addition of washing steps using guanidine thiocyanate (Knief et al., 2003). Quantification was performed using the Quant-iT ${ }^{\mathrm{TM}}$ dsDNA HS Assay Kit (Invitrogen) and extracted DNA was stored at $-20^{\circ} \mathrm{C}$ prior to ultracentrifugation separation. Heavy and light DNA were separated by density gradient ultracentrifugation using cesium chloride (CsCl) as described by Neufeld et al. (2007), with minor modifications. Five hundred nanograms to one microgram of total DNA was typically used for each SIP assay. To account for any variability in DNA distribution patterns that may arise due to using inconsistent amounts of DNA in CsCl gradients, within an individual sample set (i.e., all trials from the same sample site) similar total DNA amounts were used. Centrifugation and gradient fractionation were performed as described by Sharp et al. (2014b). DNA was precipitated from each fraction using polyethylene glycol (PEG) and glycogen as in Neufeld et al. (2007). DNA present in each density gradient was quantified using the Quant-iT ${ }^{\mathrm{TM}}$ dsDNA HS Assay Kit (Invitrogen). As the focus of this paper is assessing bacterial rather than archaeal carboxydotrophy, 16S rRNA gene PCR assays for each fraction were set-up using a QIAgility (v. 4.13.5) with bacterial specific primers 519f and 907r (Stubner, 2002). 16S rRNA gene copies were quantified on a Rotor-Gene Q (Qiagen) as in Sharp et al. (2012).

\section{Microbial Community Analysis}

The density gradients of DNA extracted from incubations with ${ }^{13} \mathrm{C}$-labeled vs. ${ }^{12} \mathrm{C}$-labeled substrates were compared. Heavy SIP fractions with increases in the relative amounts of DNA and/or 16S rRNA gene copies were selected for pyrosequencing analysis of the 16S rRNA gene. "Light" fractions (density ca. $1.690 \mathrm{~g} \mathrm{ml}^{-1}$ ) from ${ }^{13} \mathrm{CO}$ incubated samples were also analyzed in some cases for comparison to heavy fractions (Table S1). Where possible, DNA was also amplified from the corresponding heavy fractions from untreated controls (Figure 2, Table S1). However, in some cases the amount of DNA present in the fractions was below detection, or too low to obtain enough for pyrosequencing (e.g., DCm2010) (Supplementary Figure S1). Samples were prepared for sequencing analysis as described previously (Grasby et al., 2013; Sharp et al., 2014a) using FLX Titanium amplicon primers 454T_RA_X and 454T_F, which contain 16S rRNA gene targeted primers 926fw $\left(5^{\prime}\right.$-aaactYaaaKgaattgRcgg- $\left.3^{\prime}\right)$ and 1392 r ( $5^{\prime}$-acgggcggtgtgtRc- $\left.3^{\prime}\right)$ designed to target both bacteria and archaea (Ramos-Padrón et al., 2011). PCR reactions and purification were performed as described in Sharp et al. (2014a). Purified PCR products (ca. 150 ng total DNA) were analyzed at the Genome Quebec and McGill University Innovation Centre, Montreal, Quebec on a 454 Life Sciences Genome Sequencer FLX (Roche) machine running the Titanium chemistry.

\section{Sequence Data Processing}

Quantitative Insights Into Microbial Ecology (QIIME) pipeline version 1.8 (Caporaso et al., 2010) was used to process raw sequence data as in Sharp et al. (2014a). A minimum quality score of 25 was used and sequences were screened using ChimeraSlayer (Haas et al., 2011). Taxonomic identification of a representative sequence (most common) for each phylotype (clustered at 97\% similarity) was determined using nucleotide 
Basic Local Alignment Search Tool (BLAST) (Altschul et al., 1990) against the Silva 111 reference database (Pruesse et al., 2007). Eukaryotic and chloroplast sequences were removed from further analysis. Final numbers ranged from 2195 to 21118 sequences per sample (Table S1). A phylogenetic tree was constructed using the parsimony-add function in ARB (Ludwig et al., 2004).

16S rRNA gene sequences obtained from this study have been deposited in the SRA database under accession numbers SRP028305 and SRP059036. Representative sequences of identified OTUs present at 25 fold enrichment are provided in the Supplementary Material.

\section{Results}

\section{Biodegradation of Carbon Monoxide}

Anaerobic oxidation of carbon monoxide was detected via monitoring of the $\mathrm{CO}$ mixing ratio in serum bottle headspaces after adding $\mathrm{CO}$. Communities that showed evidence for $\mathrm{CO}$ consumption were selected for further investigation using stable isotope probing (SIP). The average values for anaerobic CO oxidation potentials for each sample is listed in Table 1. Rates ranged from 13.6 to $48.9 \mu \mathrm{mol} \mathrm{CO} \mathrm{g}{ }^{-1} \mathrm{~d}^{-1}$. The fastest rates were observed in samples from the Dewar Creek hot spring. Despite the anaerobic conditions, no methane production was observed in sample sites GraylingRiver1, Liard2, and PortageBrûlé1 during any incubation and only minor amounts were observed in other Dewar Creek and Lakelse samples, with estimated $\mathrm{CH}_{4}$ production rates of $0.013-11.4 \mathrm{nmol} \mathrm{mol} \mathrm{day}{ }^{-1} \mathrm{~g}^{-1}$. The amount of $\mathrm{CH}_{4}$ produced corresponds to $\mathrm{ca}$. $<0.1 \%$ of the added $\mathrm{CO}$ being converted to methane. One exception was a Lakelse sample that produced more total $\mathrm{CH}_{4}(\sim 18 \mu \mathrm{mol})$ than $\mathrm{CO}$ added, indicating other substrates were present for methanogenesis.

\section{Identification of Active CO Consuming Bacteria Using SIP Combined with 16S rRNA Gene Sequencing}

Density profiles of DNA extracted from samples after incubation with ${ }^{13} \mathrm{CO}$ generally ranged from 1.660 to $1.800 \mathrm{~g} \mathrm{ml}^{-1}$. Shifts in DNA density compared to un-amended control samples were often subtle (Supplementary Figure S1). Therefore, quantitative real-time PCR (qPCR) counts of total bacterial 16S rRNA gene abundance were used to identify density fractions that had an increase in the relative number of gene copies (Figure 1, Supplementary Figure S2).

Representative profiles of $16 \mathrm{~S}$ rRNA gene copies vs. DNA density for GraylingRiver1 (GR1) and PortageBrûlé1 (PB1) SIP experiments are shown in Figure 1. The number of 16S rRNA gene copies in the control environmental communities peaked in the density range of $1.690-1.700 \mathrm{~g} \mathrm{ml}^{-1}$. Incubations using ${ }^{12} \mathrm{CO}$ showed the same peaks, demonstrating that incubation with $\mathrm{CO}$ itself had little effect on the overall DNA density profile of the community. However, incubation of GR1 with ${ }^{13} \mathrm{CO}$ resulted in a marked shift in 16S rRNA gene copies toward heavier fractions, indicating assimilation of the ${ }^{13} \mathrm{C}$ from ${ }^{13} \mathrm{CO}$ into DNA. In contrast, no significant shift in DNA density or 16S rRNA gene copies was observed over multiple incubations of the PB1 sample under ${ }^{13} \mathrm{CO}$. Although this sample also oxidized $\mathrm{CO}$, no assimilation of ${ }^{13} \mathrm{C}$ was evident. These two samples were representative of the two major patterns observed. Other samples analyzed are shown in Supplementary Figures S1, S2.

A fundamental issue with interpreting SIP results is crosslabeling of other bacteria via metabolic products, especially $\mathrm{CO}_{2}$. The severity of this problem can be estimated via several controls. In GR1 (Figure 1A), as well as in several other samples tested (Supplementary Figures S1, S2) incubations with only ${ }^{13} \mathrm{CO}_{2}$ and no added CO always showed very minor density shifts in DNA and $16 \mathrm{~S}$ rRNA gene counts. This indicated that other autotrophs
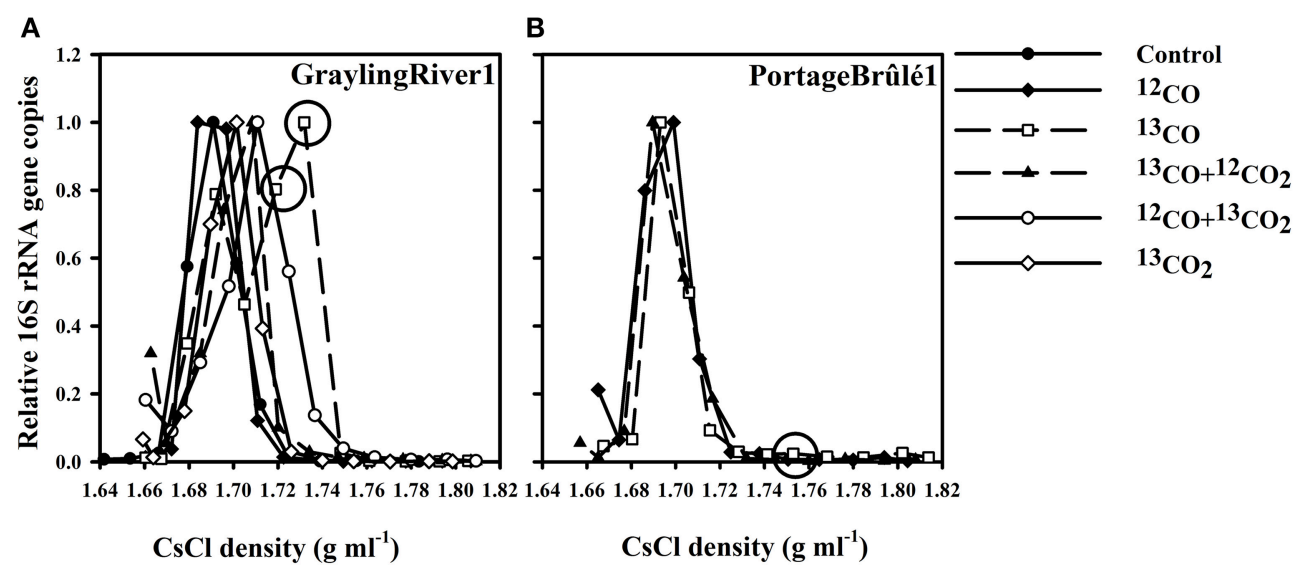

FIGURE 1 | (A) Representative 16S rRNA gene counts vs. DNA density for SIP experiments using GraylingRiver1 sediment, illustrating the shifts in relative 165 rRNA gene copies associated with different incubations. The incubations using only ${ }^{13} \mathrm{CO}$ as the sole carbon and energy source showed the greatest increase in the relative number of $16 \mathrm{~S}$ rRNA gene copies in heavy fractions at densities of approximately $1.730 \mathrm{~g} \mathrm{ml}^{-1}$. DNA from these heavy fractions was used for 16S rRNA gene pyrosequencing. (B) Relative 16S rRNA gene copies from PB1 sediment showing no density shift with ${ }^{13} \mathrm{CO}$ incubations despite active CO oxidation. Circles indicate ${ }^{13} \mathrm{CO}$ incubation fractions used for $16 \mathrm{~S}$ rRNA gene pyrosequencing analyses. "Control" represents the un-incubated (no $\mathrm{CO}$ or $\mathrm{CO}_{2}$ added) environmental sample. 
growing on substrates such as sulfur and ammonia were of minor importance. $\mathrm{CO}$ was therefore the primary energy source in the incubations, and the food webs detected were ultimately based on $\mathrm{CO}$ oxidation.

In samples like GR1, microcosms containing ${ }^{13} \mathrm{CO}$ as the sole carbon and energy source (with no $\mathrm{CO}_{2}$ addition) displayed the greatest shift in density (Figure 1). Less of a shift in density was observed in incubation with ${ }^{13} \mathrm{CO}+{ }^{12} \mathrm{CO}_{2}$, probably because assimilation of ${ }^{12} \mathrm{C}$ from the added $\mathrm{CO}_{2}$ diluted the labeling effect. Incubation with ${ }^{12} \mathrm{CO}+{ }^{13} \mathrm{CO}_{2}$ showed some increase in 16S rRNA gene copies compared to the un-incubated control, albeit to a lesser extent than in ${ }^{13} \mathrm{CO}$. The apparent assimilation of $\mathrm{C}$ preferably from ${ }^{13} \mathrm{CO}$ but also from ${ }^{13} \mathrm{CO}_{2}$ indicates that $\mathrm{CO}_{2}$ was probably the primary $\mathrm{C}$ source of the $\mathrm{CO}$ oxidizers, but that there may be a diffusion effect whereby the ${ }^{13} \mathrm{CO}_{2}$ produced directly by a carboxydotroph from ${ }^{13} \mathrm{CO}$ is preferentially assimilated compared to exogenous ${ }^{12} \mathrm{CO}_{2}$ supplied in the atmosphere.

In the majority of cases, the "heavy" fractions that showed the greatest increase in 16S rRNA gene copies were at a density of ca. $1.730 \mathrm{~g} \mathrm{ml}^{-1}$ (Figure 1, Supplementary Figure S2). Heavy fractions that contained a large increase in DNA amounts and/or 16S rRNA gene copies as compared to an un-incubated, nonlabeled control were selected for 16S rRNA gene sequencing. In some cases (e.g., DCm2010), the amount of DNA present in the corresponding high-density fractions of the unlabeled controls was too low to obtain enough for successful pyrotag sequencing despite inputs of similar total amounts of DNA (see Supplementary Figure S1).

Most predominant operational taxonomic units (OTUs) in the heavy fractions of all samples (i.e., most putative carboxydotrophs) belonged to the phylum Firmicutes, in particular to the class Clostridia. In heavy fractions recovered from ${ }^{13} \mathrm{CO}$ incubations that showed observable shifts in $16 \mathrm{~S}$ rRNA gene copies, members of the phylum Firmicutes accounted for $31-95 \%$ of the reads (Table S1). One of the lowest \% of Firmicutes was from GR1 which had a very high proportion of Crenarchaeota in both the original community and in all heavy fractions. However, of bacterial sequences only, Firmicutes accounted for $81.5 \%$ in the heavy fraction of GR1_ ${ }^{13} \mathrm{CO}$. The proportions of top phyla ( $>1 \%$ of sequences) of both the unamended environmental samples and the heavy fractions for two sites that showed strong DNA labeling are shown in Figure 2.

The taxonomic identifications of OTUs recovered from ${ }^{13} \mathrm{CO}$ microcosm heavy fractions that were present at 25 fold enrichment compared to the original environmental sample are shown in Table 2. A 16S rRNA gene phylogenetic tree was constructed using the top OTUs from each ${ }^{13} \mathrm{CO}$ heavy fraction showing an observable shift compared to reference sequences (Figure 3). Taxonomic identifications of OTUs present at $>1 \%$ of all sequences are presented in Supplementary Table S2. Most of the putative carboxydotrophs identified belonged with $>98 \%$ sequence identity to genera that include known CO-oxidizers, such as Thermincola, Desulfotomaculum, Carboxydocella, and Thermolithobacter (Sokolova et al., 2002, 2005, 2007; Parshina et al., 2005a,b). For example, the most abundant OTU (OTU_17948) recovered from ${ }^{13} \mathrm{CO}$ heavy fractions from Dewar Creek (DCm2010 and DCmN11) and Lakelse springs showed 99\% sequence identity to both Thermincola potens and to Thermincola carboxydiphila, known CO-oxidizing bacteria (Sokolova et al., 2005; Byrne-Bailey et al., 2010) (Table 2). Members of the genus Carboxydocella were

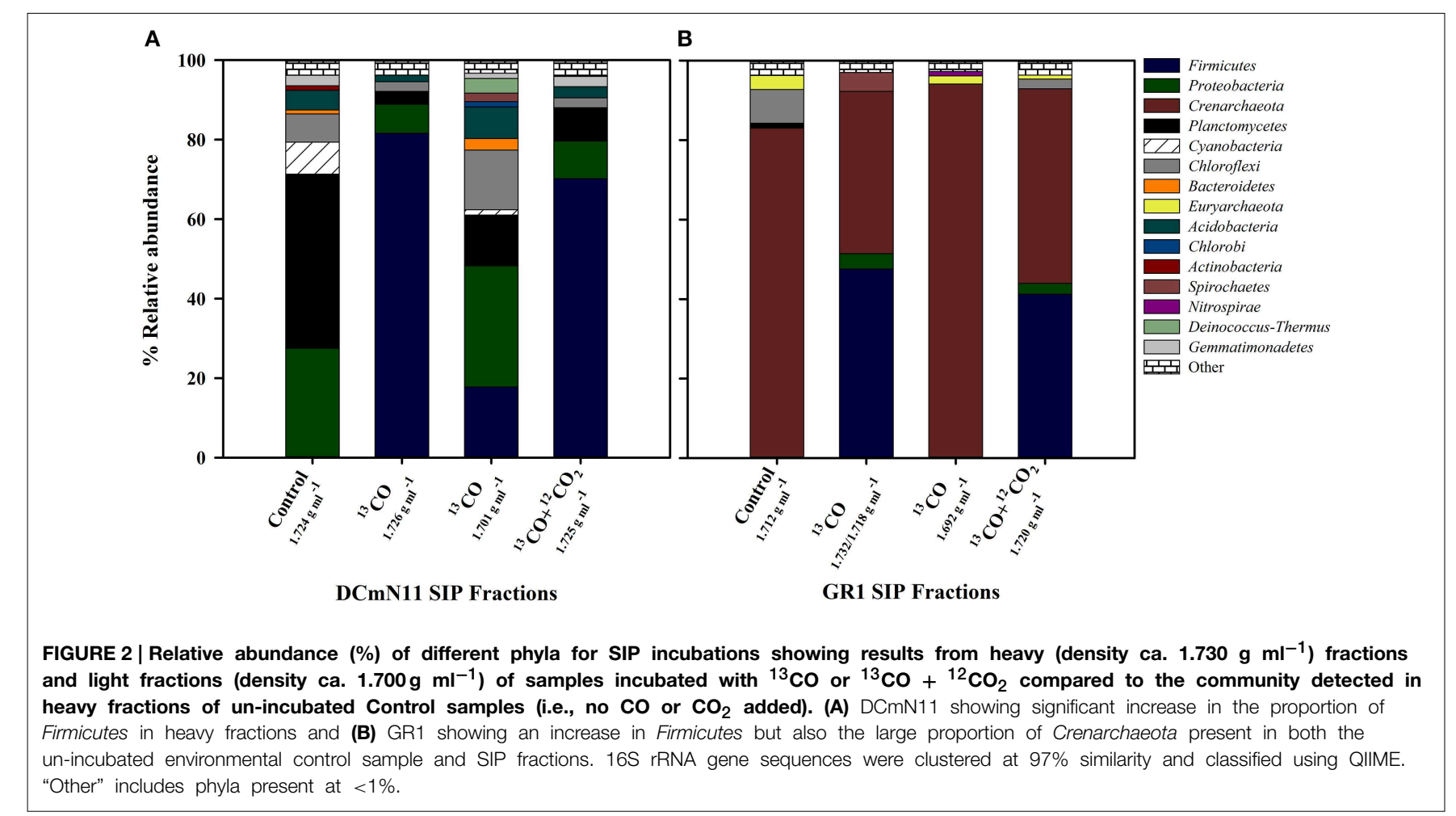


TABLE 2 | The percent of total sequences associated with top OTUs identified in heavy fractions of ${ }^{13} \mathrm{CO}$ incubations.

\begin{tabular}{|c|c|c|c|c|c|c|c|c|c|c|}
\hline OTU & Phylum & BLAST identification & $\begin{array}{l}\text { Identity } \\
\text { (\%) }\end{array}$ & $\begin{array}{l}\text { DCm2010 } \\
1.733 \mathrm{~g} \mathrm{ml}^{-1}\end{array}$ & $\begin{array}{c}\text { DCmN11 } \\
1.726 \mathrm{~g} \mathrm{ml}^{-1}\end{array}$ & $\begin{array}{c}\text { DCs9 } \\
1.740 \mathrm{~g} \mathrm{ml}^{-1}\end{array}$ & $\begin{array}{c}\text { L3 } \\
1.721 \mathrm{~g} \mathrm{ml}^{-1}\end{array}$ & $\begin{array}{c}\text { GR1 } \\
1.726 \mathrm{~g} \mathrm{ml}^{-1}\end{array}$ & $\begin{array}{c}\text { Liard2 } \\
1.734 \mathrm{~g} \mathrm{ml}^{-1}\end{array}$ & $\begin{array}{c}\text { PB1 } \\
0.753 \mathrm{~g} \mathrm{ml}^{-1}\end{array}$ \\
\hline 3148 & Firmicutes & $\begin{array}{l}\text { Desulfotomaculum } \\
\text { kuznetsovii/D. luciae }\end{array}$ & 99 & & & 30.0 (n.d.) & & & & \\
\hline 3442 & Firmicutes & $\begin{array}{l}\text { Thermolithobacter } \\
\text { carboxydivorans }\end{array}$ & 100 & & & 8.9 (n.d.) & & & & \\
\hline 7600 & Firmicutes & $\begin{array}{l}\text { Carboxydocella } \\
\text { thermautrotrophica }\end{array}$ & 98 & 7.6 (n.d.) & 2.9 (n.d.) & $17.9(0.0)$ & & 17.0 (n.d.) & 28.0 (n.d.) & \\
\hline 9076 & Firmicutes & $\begin{array}{l}\text { Sporomusa } \\
\text { sphaeroides }\end{array}$ & 94 & & & & & & & 15.7 (n.d.) \\
\hline 12486 & Firmicutes & $\begin{array}{l}\text { Caloramator } \\
\text { australicus }\end{array}$ & 99 & & & & 7.3 (n.d.) & & & \\
\hline 14221 & Firmicutes & $\begin{array}{l}\text { Desulfurispora } \\
\text { thermophila }\end{array}$ & 97 & & 1.6 (n.d.) & & $7.5(0.0)$ & & & \\
\hline 17597 & Firmicutes & $\begin{array}{l}\text { Streptococcus } \\
\text { thermophilus }\end{array}$ & 100 & & & & & & & 26.7 (n.d.) \\
\hline 17948 & Firmicutes & $\begin{array}{l}\text { Thermincola potens/ } \\
\text { T. carboxydiphila }\end{array}$ & 99 & 68.2 (n.d.) & 65.5 (n.d.) & & 48.4 (n.d.) & 3.9 (n.d.) & & \\
\hline 17986 & Firmicutes & $\begin{array}{l}\text { Thermincola potens/ } \\
\text { T. carboxydiphila }\end{array}$ & 90 & & & 8.1 (n.d.) & & & & \\
\hline 18478 & $\begin{array}{l}\text { Deinococcus- } \\
\text { Thermus }\end{array}$ & Thermus scotoductus & 100 & & & $5.4(0.2)$ & & & & \\
\hline 20883 & Firmicutes & $\begin{array}{l}\text { Candidatus } \\
\text { Desulforudis } \\
\text { audaxviator }\end{array}$ & 93 & & & & & 15.1 (n.d.) & & \\
\hline 21098 & Proteobacteria & Azonexus caeni & 98 & & & & & & & $19.3(0.2)$ \\
\hline
\end{tabular}

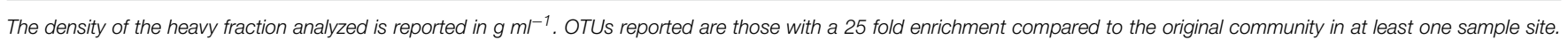

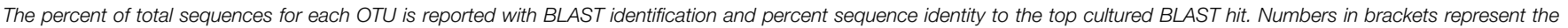
proportion (\%) of sequences present in the same OTU in the original environmental sample. n.d., not detected.

also detected in the majority of heavy fractions across all sites. This genus was represented by multiple OTUs, however the top OTU_7600 identified in most samples corresponded to Carboxydocella thermautotrophica (98\% similarity). Members of the genus Desulfotomaculum were most predominant in DCs9, a sediment sample collected from Dewar Creek. In DCs9_ ${ }^{13} \mathrm{CO}$ incubations, $31.9 \%$ of sequences were attributed to the genus Desulfotomaculum. $30.0 \%$ of sequences were in OTU_3148, which showed $99 \%$ sequence identity to D. kuznetsovii and D. luciae.

Some OTUs identified may reflect bacteria with as yet unknown or unconfirmed CO-oxidizing capabilities. One such cluster, OTU_20883, present in both the GR1_ ${ }^{13} \mathrm{CO}$ and GR1 $1{ }^{13} \mathrm{CO}+{ }^{12} \mathrm{CO}_{2}$ heavy fraction at 15.1 and $5.3 \%$ of sequences respectively, is $93 \%$ similar to Candidatus "Desulforudis audaxviator." Neither this OTU nor any others that showed any similarity to this bacterium were detected in the control environmental sample from this site. BLAST results for OTU_17986 representing $8.1 \%$ of the total for DCs9_ ${ }^{13} \mathrm{CO}$ returned equal results for Thermincola potens and Thermincola carboxydiphila. However, the sequence identity to both was only 90\%, and it branches distantly from Thermincola in the phylogenetic tree (Figure 3). This may represent another related $\mathrm{CO}$-oxidizing genus, the exact nature of which requires further study.
While PB1 and Liard2 sediments did oxidize CO, incubations with ${ }^{13} \mathrm{CO}$ did not show any observable shift in $16 \mathrm{~S}$ rRNA gene density profiles. Nevertheless, we did for comparison analyze the heavy fractions from these incubations. The heavy fraction of PB1 showed a slight increase in Firmicutes as compared to the proportion present in the original community (Table S1), however no OTUs with sequences $>1 \%$ were associated with known CO-oxidizing bacteria (Table S2). In comparison, the heavy fraction from Liard2 ${ }^{13} \mathrm{CO}$ had a number of OTUs associated with CO-oxidizing bacteria. Only one OTU was present at 25 fold enrichment and represented the top OTU of this fraction (Table 2). OTU_7600 had a 98\% BLAST identity to Carboxydocella thermoautotrophica. It represented $28.0 \%$ of sequences and was the same Carboxydocella OTU found in other sites at relatively high abundance. Therefore, growth of carboxydotrophs was probably occurring in these samples as well, albeit at slow rates.

High $\mathrm{G}+\mathrm{C}$ content may be responsible for the observation of some organisms in heavy fractions, including uncultured Crenarchaeota present in heavy fractions recovered from GR1_ ${ }^{13} \mathrm{CO}$ (Table 2). The G + C content of previously identified CO-oxidizing thermophiles ranges from ca. 40-48\% (Svetlichny et al., 1991b; Sokolova et al., 2002, 2004, 2005), corresponding to a density range of $1.698-1.705 \mathrm{~g} \mathrm{ml}^{-1}$. Increased $\mathrm{G}+\mathrm{C}$ content results in a higher buoyant density that may initially suggest 


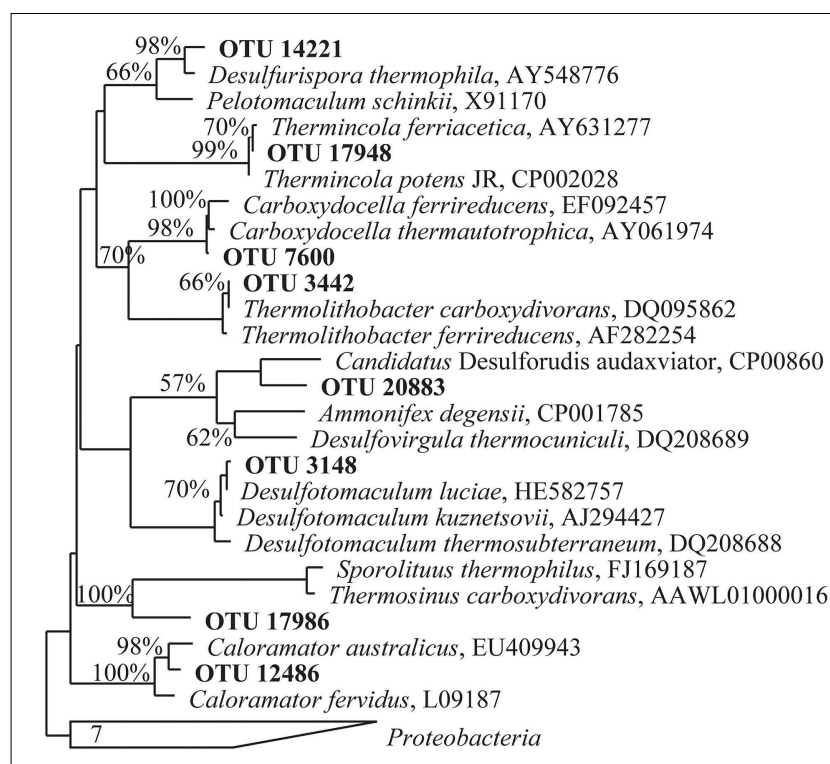

0.10

FIGURE 3 | Phylogenetic tree of partial 16S rRNA gene sequences belonging to OTUs identified in heavy fractions from ${ }^{13} \mathrm{CO}$ SIP incubations present at a minimum of $\mathbf{2 5}$ fold enrichment. OTUs presented are from those incubations that showed an observable shift in density and are hypothesized to represent microbes that oxidized CO. A skeleton tree was constructed from near complete 16S rRNA gene sequences (>1400 bp) via Neighbor-joining with a Jukes-Cantor correction and 10,000 bootstraps. Shorter sequences produced via 454 pyrosequencing obtained in this study were added by parsimony using ARB (in bold). The scale bar represents 0.1 change per nucleotide position. Bootstrap support values greater than 55\% for the major nodes are given. The tree was rooted using 7 Proteobacteria $16 \mathrm{~S}$ rRNA gene sequences.

${ }^{13} \mathrm{C}$ incorporation (Schildkraut et al., 1962). However, the high proportions in un-amended and ${ }^{12} \mathrm{C}$ controls of Crenarchaeota in the case of GR1 suggest that these microbes were not carboxydotrophs but rather are naturally present at that density due to relatively high $\mathrm{G}+\mathrm{C}$ content.

\section{Discussion}

In this study, bacteria potentially involved in the anaerobic oxidation of carbon monoxide were identified from hot spring environments using DNA-SIP. Five geographically diverse geological settings were identified in which potential anaerobic CO-oxidation was detectable. These five locations are widely dispersed geographically over an area of approximately 1 million $\mathrm{km}^{2}$. The measured CO-oxidation potentials were variable between geothermal springs. Comparative rates from other environments are rarely reported, however CO-oxidation rates of $120 \mu \mathrm{mol}^{-1}$ of sediment $\mathrm{d}^{-1}$ were estimated in slurries from Uzon Caldera, Kamchatka (Kochetkova et al., 2011), and a ${ }^{14} \mathrm{CO}$ tracer was used to estimate a rate of $40.75 \mathrm{nmol} \mathrm{CO} \mathrm{cm}^{-3}$ sediment $\mathrm{d}^{-1}$ for another anaerobic hot spring community in Kamchatka (Slepova et al., 2007). While obtained following different methodology, these in vitro rate estimates are 2-4 orders of magnitude lower than those measured in the present study, and show that potential rates of $\mathrm{CO}$ oxidation may vary greatly between environments. The observation of little to no methane production in most samples was consistent with the negligible proportions of Euryarchaeota detected in the original environmental communities and the lack of archaeal sequences detected in heavy SIP fractions (e.g., Figure 2A).

Distinct differences were noted between the original microbial communities and the communities detected in ${ }^{13} \mathrm{C}$-labeled heavy DNA fractions for each sample. In most cases, Firmicutes were present at $<1 \%$ in the original communities but increased in abundance in ${ }^{13} \mathrm{CO}$ incubated heavy fractions, reaching up to ca. $95 \%$ of all $16 \mathrm{~S}$ rRNA gene reads (Table S1). These results indicate that CO-metabolizing bacteria make up a relatively minor component of the overall population within these geothermal systems but are still present and may become active if $\mathrm{CO}$ is provided. Most of the bacteria identified in heavy fractions showed high identities (>98\%) to known CO-oxidizing bacteria described from other geothermal springs, particularly Carboxydocella and Thermincola species (Table 2). This finding suggests not only that the CO-SIP procedure was successful in identifying primary carboxydotrophs without cross-feeding artifacts, but also that the predominant carboxydotrophic bacteria in geothermal environments may in fact already be well described from cultivation studies. This is a rather unusual finding for SIP experiments (e.g., Redmond et al., 2010). Geographically, it also indicates that anaerobic thermophilic carboxydotrophic bacteria are highly cosmopolitan (at least at the species/genus level), since most described isolates have been obtained from Russian geothermal sites. Aerobic carobyxdotrophy is taxonomically diverse (e.g., King and Weber, 2007). And while the presence of CO in geothermal spring emissions may suggest the potential for wide-spread CO metabolism, the current study supports the notion that the capacity for anaerobic carboxydotrophy among thermophiles is more limited.

While the most predominant bacteria identified via SIP were similar to carboxydotrophs isolated from other geothermal springs, there were a few exceptions. Among the predominant OTUs detected in heavy DNA fractions (Table 2), three OTUs showed $<95 \% 16 \mathrm{~S}$ rRNA gene sequence identity to any described species. For example, an OTU making up 15\% of the heavy DNA fraction in sample GR1 had only a moderate similarity to the proposed genus "Desulforudis." Candidatus "Desulforudis audaxviator" was identified in the fracture water of a South African gold mine. This isolate has components of the WoodLjungdahl pathway and may be capable of $\mathrm{CO}$ oxidation and assimilation (Chivian et al., 2008). However, the low identity (93\%) of our OTU indicates a genus-level divergence to $\mathrm{Ca}$. "D. audaxviator."

While the use of $16 \mathrm{~S}$ rRNA gene qPCR greatly improved the detection of shifts in density within the $\mathrm{CsCl}$ gradients, in general the observed shifts were subtle. Approximately $0.47 \mathrm{mmol}$ of total ${ }^{13} \mathrm{C}$ was added to each of the ${ }^{13} \mathrm{CO}$ SIP incubations. However, previous studies show that relatively little of the CO oxidized microbially in geothermal habitats is incorporated into 
biomass. Using radioisotope tracers to examine a hot spring community from Kamchatka, it was estimated that $85 \%$ of the ${ }^{14} \mathrm{CO}$ was oxidized to $\mathrm{CO}_{2}$ while only $0.5 \%$ was used for cell biomass production. The remainder was distributed between dissolved organic matter and minor (0.001\%) amounts of methane (Slepova et al., 2007). At $0.5 \%$ incorporation, a maximum of ca. $2.35 \mu \mathrm{mol}$ of ${ }^{13} \mathrm{C}$ would have been incorporated into the bacteria identified in the current study and may explain why shifts in the density of labeled DNA were minor compared to SIP experiments using substrates such as ${ }^{13} \mathrm{CH}_{4}$ where more $\mathrm{C}$ is incorporated into the cells over a short incubation period (Dumont et al., 2011). The use of qPCR and the examination of the $16 \mathrm{~S}$ rRNA gene copy profiles provided a means by which to identify subtle shifts in DNA density (Lueders et al., 2004; Sharp et al., 2012). The lack of observable shifts in 16S rRNA gene copies in one of our samples $\left({ }^{13} \mathrm{CO}\right.$-incubated PortageBrûlé) indicated that some geothermal communities may contain bacteria that are using $\mathrm{CO}$ as an energy source to maintain the population but are perhaps growing slowly, maybe due to other nutrient limitations, or more likely are incorporating other, possibly organic, $\mathrm{C}$ sources into biomass (Figure 1B). This does indicate limitations in the ${ }^{13}$ CO-SIP technique. While it appeared to be effective in identifying some carboxydotrophs, it cannot identify all of these metabolically diverse microorganisms including potential carboxydoheterotrophs.

The ${ }^{13}$ CO-SIP technique is also challenging because carboxydotrophs may incorporate $\mathrm{CO}_{2}$ rather than $\mathrm{CO}$ directly, and because the initial products of $\mathrm{CO}$-oxidation, $\mathrm{H}_{2}$ and $\mathrm{CO}_{2}$, may lead to labeling of other autotrophs. Our experiments included controls suggesting that these problems were minor. The greatest shifts in density were observed when ${ }^{13} \mathrm{CO}$ was provided as the sole carbon source (i.e., no extra $\mathrm{CO}_{2}$ was added), but incubations with ${ }^{13} \mathrm{CO}+{ }^{12} \mathrm{CO}_{2}$ showed smaller shifts in DNA density compared to ${ }^{13} \mathrm{CO}$ alone. Most likely, an initial oxidation of ${ }^{13} \mathrm{CO}$ to ${ }^{13} \mathrm{CO}_{2}$ via the gas-water shift reaction is followed by assimilation of the produced ${ }^{13} \mathrm{CO}_{2}$. Incubations with ${ }^{13} \mathrm{CO}_{2}$ alone (and no $\mathrm{CO}$ added) showed little or no apparent shifts in DNA density, indicating that labeling of autotrophs growing on substrates already present in the samples, such as sulfur or ammonia, was not an issue, and that $\mathrm{CO}$ was ultimately the primary energy source in the incubations. However, there is the distinct possibility of hydrogenotrophic organisms using the $\mathrm{H}_{2}$ and ${ }^{13} \mathrm{CO}_{2}$ produced via the gas-water shift reaction. This particular form of cross-feeding cannot be eliminated from the current results, but lines of evidence suggest that it was minor: (1) Cross-feeding with $\mathrm{H}_{2}$ may occur only in addition to primary $\mathrm{CO}$ oxidation- i.e., it can only be a secondary process given that $\mathrm{CO}$ was the major energy source available; (2) almost all of the detected bacteria in the present study were closely related to known carboxydotrophs; and (3) potentially hydrogenotrophic but non-carboxydotrophic bacteria such as the members of the phylum Deinococcus-Thermus were detected in some heavy DNA fractions, but were always of minor importance compared to known carboxydotrophs (e.g., Thermus scotoductus in DCs9, Table 2; Table S2). Complete genomes of both T. scotoductus and T. antranikianii (Table S2) lack genes related to CO metabolism (http://img.jgi.doe.gov/).
Many bacterial species that possess $\operatorname{cooS}$ genes have a primary metabolism that does not focus on $\mathrm{CO}$, however their presence may imply a potential underlying or backup CO-dependent physiology should conditions vary and become more optimal for CO-oxidation (Techtmann et al., 2011). While challenging to measure in situ, localized accumulations of $\mathrm{CO}$ may create microniches within geothermal systems in which low abundance carboxydotrophic population members may thrive. For example, the species composition of the heavy fractions was similar for two biomat samples DCm2010 and DCmN11 with a dominance of Thermincola potens in both cases. The presence of CO oxidizing bacteria in these samples is perhaps not surprising given the observation of net CO production within microbial mats. Saline and intertidal sand flat photosynthetic microbial mats exhibited a net production of $\mathrm{CO}\left(3.1-5.4 \mu \mathrm{mol} \mathrm{m} \mathrm{m}^{-2} \mathrm{~d}^{-1}\right)$ during daylight hours and were also observed to have a net production of $\mathrm{H}_{2}$ (Hoehler et al., 2001). As many of the Dewar Creek samples that showed evidence of CO-oxidation were comprised of biomats with relatively high proportions of cyanobacteria (Figure 2B, Table S1), these results support $\mathrm{CO}$ as a potentially important carbon and energy source in microenvironments within geothermal systems. Variation in $\mathrm{CO}$ metabolizing bacteria was observed between samples collected from the same geothermal system but under different temperature regimes. OTU_3148 was $99 \%$ similar to both Desulfotomaculum kuznetsovii and Desulfotomaculum luciae, detected in ${ }^{13} \mathrm{CO}$ incubations of DCs9, another site from the Dewar Creek hot spring. Desulfotomaculum kuznetsovii is an obligate anaerobe and is capable of growth with $\mathrm{CO}$ as the sole carbon and energy source (Parshina et al., 2005a). Thermolithobacter carboxydivorans was also detected in this particular sample site but was not detected in any other microcosm. The optimum growth temperature for $T$. carboxydivorans of $70^{\circ} \mathrm{C}$ may also explain the presence of this bacterium in DCs9 with an environmental and incubation temperature of $65^{\circ} \mathrm{C}$ as opposed to other Dewar Creek samples with lower in situ temperatures incubated at $55^{\circ} \mathrm{C}$ (Sokolova et al., 2005).

The dominance of Firmicutes in heavy-density DNA fractions of geothermal samples incubated under ${ }^{13} \mathrm{CO}$ confirms that representatives of this phylum may play a predominant role relative to other phyla in anaerobic oxidation of $\mathrm{CO}$ in geothermal environments. In particular, they may reflect minor populations within geothermal microenvironments where localized CO concentrations may be high. While the detection of such microenvironments in situ is challenging, the hypothesized presence of these localized CO-rich niches (e.g., Techtmann et al., 2009) suggests a mechanism by which these carboxydotrophs may exist. Despite comprising a relatively small proportion of in situ communities, the CO oxidizing bacteria are active and show some variation across geothermal environments. Oxidation potentials are higher than the few previously reported rates for mixed geothermal communities. Despite geographical differences, thermophilic bacteria associated with anaerobic CO-oxidation are widely distributed geographically and the predominant species are well-described from cultivation studies. The presence of a few OTUs that do not show high degrees of similarity to any known cultured representatives indicates that a 
few new lithoautotrophs that have not been previously identified as $\mathrm{CO}$-oxidizers may also be present in the geothermal springs tested and require further study.

The detection of sequences associated with known COoxidizing bacteria in high abundance supports the applicability of the CO-SIP technique. SIP can be applied to target autotrophs by adding an energy substrate along with ${ }^{13} \mathrm{CO}_{2}$. This works as long as the added substrate is the primary energy source for the autotrophic community. We have previously used this approach to identify autotrophic methanotrophs (Sharp et al., 2012). We therefore conclude that the CO-SIP technique, which works in a similar way to identify autotrophic carboxydotrophs, does have some value, although of course the results still need to be interpreted with caution. Controls are necessary to demonstrate a low rate of assimilation of ${ }^{13} \mathrm{CO}_{2}$ by other autotrophs. It should also be stressed that heterotrophic carboxydotrophs will be missed- this was a possible explanation for the failure of some of the samples assayed in this study. Cross feeding via $\mathrm{H}_{2}+$ $\mathrm{CO}_{2}$ produced via the gas-water shift reaction is also a potential issue, although this appeared to be minor in this particular study. This study appeared to work because the bacteria identified were primarily known carboxydotrophs, however identification of a new potential carboxydotroph should only be taken as initial evidence that requires verification with other methods including sequencing of potential coos genes.

\section{References}

Altschul, S. F., Gish, W., Miller, W., Myers, E. W., and Lipman, D. J. (1990). Basic local alignment search tool. J. Mol. Biol. 215, 403-410. doi: 10.1016/S00222836(05)80360-2

Berg, I. A. (2011). Ecological aspects of the distribution of different autotrophic $\mathrm{CO}_{2}$ fixation pathways. Appl. Environ. Microbiol. 77, 1925-1936. doi: 10.1128/AEM.02473-10

Byrne-Bailey, K. G., Wrighton, K. C., Melnyk, R. A., Agbo, P., Hazen, T. C., and Coates, J. D. (2010). Complete genome sequence of the electricityproducing "Thermincola potens" strain JR. J. Bacteriol. 192, 4078-4079. doi: 10.1128/JB.00044-10

Caporaso, J. G., Kuczynski, J., Stombaugh, J., Bittinger, K., Bushman, F. D., Costello, E. K., et al. (2010). QIIME allows analysis of highthroughput community sequencing data. Nat. Methods 7, 335-336. doi: 10.1038/nmeth.f.303

Cavicchioli, R. (2002). Extremophiles and the search for extraterrestrial life. Astrobiology 2, 281-292. doi: 10.1089/153110702762027862

Chivian, D., Brodie, E. L., Alm, E. J., Culley, D. E., Dehal, P. S., DeSantis, T. Z., et al. (2008). Environmental genomics reveals a single-species ecosystem deep within Earth. Science 322, 275-278. doi: 10.1126/science.1155495

Conrad, R. (1988). Biogeochemistry and ecophysiology of atmospheric CO and $\mathrm{H}_{2}$. Adv. Microb. Ecol. 10, 231-283. doi: 10.1007/978-1-4684-5409-3_7

Conrad, R. (1996). Soil microorganisms as controllers of atmospheric trace gases $\left(\mathrm{H}_{2}, \mathrm{CO}, \mathrm{CH}_{4}, \mathrm{OCS}, \mathrm{N}_{2} \mathrm{O}\right.$ and NO). Microbiol. Rev. 60, 609-640.

Dobbek, H., Svetlitchnyi, V., Gremer, L., Huber, R., and Meyer, O. (2001). Crystal structure of a carbon monoxide dehydrogenase reveals a [Ni-4Fe-5S] cluster. Sci. New Ser. 293, 1281-1285. doi: 10.1126/science.1061500

Dumont, M. G., Pommerenke, B., Casper, P., and Conrad, R. (2011). DNA-, rRNA- and mRNA-based stable isotope probing of aerobic methanotrophs in lake sediment. Environ. Microbiol. 13, 1153-1167. doi: 10.1111/j.14622920.2010.02415.x

Giggenbach, W. F. (1980). Geothermal gas equilibria. Geochim. Cosmochim. Acta 44, 2021-2032. doi: 10.1016/0016-7037(80)90200-8

Grasby, S. E., Hutcheon, I., and Krouse, H. R. (2000). The influence of water-rock interaction on the chemistry of thermal springs in western

\section{Author Contributions}

$\mathrm{AB}, \mathrm{CS}$ and SG collected samples; $\mathrm{AB}$ performed SIP incubations with input from $\mathrm{PD} ; \mathrm{AB}$ with aid from $\mathrm{CS}$ extracted DNA, prepared samples for sequencing and carried out data processing. $\mathrm{AB}$ and $\mathrm{PD}$ wrote the initial draft of the paper; all authors designed the study, discussed the results and commented on the manuscript.

\section{Acknowledgments}

Funding was provided by an Alberta Innovates Technology Futures (AITF) New Faculty Award grant to PD and in part by a Natural Science and Engineering Research Council of Canada (NSERC) Post-Doctoral Fellowship and PEO Scholar Award to AB. CS was supported by fellowships from NSERC and AITF. We thank B. C. Parks for permission to sample Dewar Creek.

\section{Supplementary Material}

The Supplementary Material for this article can be found online at: http://journal.frontiersin.org/article/10.3389/fmicb. 2015.00897

Canada. Appl. Geochem. 15, 439-454. doi: 10.1016/S0883-2927(99) 00066-9

Grasby, S. E., Richards, B., Sharp, C. E., Brady, A. L., Jones, G. M., and Dunfield, P. F. (2013). The Paint Pots, Kootenay National Park, Canada - A natural acid spring analogue for Mars. Can. J. Earth Sci. 50, 94-108 doi: 10.1139/e2012-060

Haab, P. (1990). The effect of carbon monoxide on respiration. Experientia 46, 1202-1206. doi: 10.1007/BF01936937

Haas, B. J., Gevers, D., Earl, A. M., Feldgarden, M., Ward, D. V., Giannoukos, G., et al. (2011). Chimeric $16 \mathrm{~S}$ rRNA sequence formation and detection in Sanger and 454-pyrosequenced PCR amplicons. Genome Res. 21, 494-504. doi: 10.1101/gr.112730.110

He, R., Wooller, M. J., Pohlman, J. W., Quensen, J., Tiedje, J. M., and Leigh, M. B. (2012). Diversity of active aerobic methanotrophs along depth profiles of artic and subarctic lake water column and sediments. ISME J. 6, 1937-1948. doi: 10.1038/ismej.2012.34

Henstra, A. M., Dijkema, C., and Stams, A. J. M. (2007a). Archaeoglobus fulgidus couples $\mathrm{CO}$ oxidation to sulfate reduction and acetogenesis with transient formate accumulation. Environ. Microbiol. 9, 1836-1841. doi: 10.1111/j.14622920.2007.01306.x

Henstra, A. M., Sipma, J., Rinzema, A., and Stams, A. J. M. (2007b). Microbiology of synthesis gas fermentation for biofuel production. Curr. Opin. Biotechnol. 18, 200-206. doi: 10.1016/j.copbio.2007.03.008

Hoehler, T. M., Bebout, B. M., and Des Marais, D. J. (2001). The role of microbial mats in the production of reduced gases on early Earth. Nature 412, 324-327. doi: $10.1038 / 35085554$

Kerby, R. L., Ludden, P. W., and Roberts, G. P. (1995). Carbon monoxidedependent growth of Rhodospirillum rubrum. J. Bacteriol. 177, 2241-2244.

King, G. M., and Weber, C. F. (2007). Distribution, diversity and ecology of aerobic CO-oxidizing bacteria. Nat. Rev. 5, 107-118. doi: 10.1038/nrmicro1595

Knief, C., Lipski, A., and Dunfield, P. F. (2003). Diversity and activity of methanotrophic bacteria in different upland soils. Appl. Environ. Microbiol. 69, 6703-6714. doi: 10.1128/AEM.69.11.6703-6714.2003

Kochetkova, T. V., Rusanov, I. I., Pimenov, N. V., Kolganova, T. V., Lebedinsky, A. V., Bonch-Osmolovskaya, E. A., et al. (2011). Anaerobic transformation of carbon monoxide by microbial communities of Kamchatka hot springs. Extremophiles 15, 319-325. doi: 10.1007/s00792-011-0362-7 
Lee, H. S., Kang, S. G., Bae, S. S., Lim, J. K., Cho, Y., Kim, Y. J., et al. (2008). The complete genome sequence of Thermococcus onnurineus NA1 reveals a mixed heterotrophic and carboxydotrophic metabolism. J. Bacteriol. 190, 7491-7499. doi: 10.1128/JB.00746-08

Ludwig, W., Strunk, O., Westram, R., Richter, L., Meier, H., Yadhukumar, B. A., et al. (2004). Arb: a software environment for sequence data. Nucleic. Acids Res. 32, 1363-1371. doi: 10.1093/nar/gkh293

Lueders, T., Manefield, M., and Friedrich, M. W. (2004). Enhanced sensitivity of DNA- and rRNA-based stable isotope probing by fractionation and quantitative analysis of isopycnic centrifugation gradients. Environ. Microbiol. 6, 73-78. doi: 10.1046/j.1462-2920.2003.00536.x

Mörsdorf, G., Frunzke, K., Gadkari, D., and Meyer, O. (1992). Microbial growth on carbon monoxide. Biodegradation 3, 61-82. doi: 10.1007/BF00189635

Neufeld, J. D., Vohra, J., Dumont, M. G., Lueders, T., Manefield, M., Friedrich, M. W., et al. (2007). DNA stable-isotope probing. Nature 2, 860-866. doi: 10.1038/nprot.2007.109

Novikov, A. A., Sokolova, T. G., Lebedinsky, A. V., Kolganova, T. V., and Bonch-Osmolovskaya, E. A. (2011). Carboxydothermus islandicus sp. nov., a thermophilic, hydrogenogenic, carboxydotrophic bacterium isolated from a hot spring. Int. J. Syst. Evol. Microbiol. 61, 2532-2537. doi: 10.1099/ijs.0. 030288-0

Oelgeschläger, E., and Rother, M. (2008). Carbon monoxide-dependent energy metabolism in anaerobic bacteria and archaea. Arch. Microbiol. 190, 257-269. doi: 10.1007/s00203-008-0382-6

Parshina, S. N., Kijlstra, S., Henstra, A. M., Sipma, J., Plugge, C. M., and Stams, A. J. M. (2005a). Carbon monoxide conversion by thermophilic sulfate-reducing bacteria in pure culture and in co-culture with Carboxydotherms hydrogenoformas. Appl. Microbiol. Biotechnol. 68, 390-396. doi: 10.1007/s00253-004-1878-x

Parshina, S. N., Sipma, J., Nakashimada, Y., Henstra, A. M., Smidt, H., Lysenko, A. M., et al. (2005b). Desulfotomaculum carboxydivorans sp. nov., a novel sulfatereducing bacterium capable of growth at $100 \%$ CO. Int. J. Syst. Evol. Microbiol. 55, 2159-2165. doi: 10.1099/ijs.0.63780-0

Pruesse, E., Quast, C., Knittel, K., Fuchs, B. M., Ludwig, W., Peplies, J., et al. (2007). SILVA: a comprehensive online resource for quality checked and aligned ribosomal RNA sequence data compatible with ARB. Nucleic Acids Res. 35, 7188-7196. doi: 10.1093/nar/gkm864

Ragsdale, S. W. (1991). Enzymology of the acetyl-CoA pathway of $\mathrm{CO}_{2}$ fixation. Crit. Rev. Biochem. Mol. 26, 261-300. doi: 10.3109/10409239109114070

Ragsdale, S. W. (2004). Life with carbon monoxide. Crit. Rev. Biochem. Mol. 39, 165-195. doi: 10.1080/10409230490496577

Ramos-Padrón, E., Bordenave, S., Lin, S., Bhaskar, I. M., Dong, X., Sensen, C. W., et al. (2011). Carbon and sulfur cycling by microbial communities in a gypsum-treated oil sands tailings pond. Environ. Sci. Technol. 45, 439-446. doi: $10.1021 /$ es1028487

Redmond, M. C., Valentine, D. L., and Sessions, A. L. (2010). Identification of novel methane-, ethane-, and propane-oxidizing bacteria at marine hydrocarbon seeps by stable isotope probing. Appl. Environ. Microbiol. 76, 6412-6422. doi: 10.1128/AEM.00271-10

Schildkraut, C. L., Marmu, J., and Doty, P. (1962). Determination of the base composition of deoxyribonucleic acid from its buoyant density in $\mathrm{CsCl}$. J. Mol. Biol. 4, 430-443. doi: 10.1016/S0022-2836(62)80100-4

Sharp, C. E., Brady, A. L., Sharp, G. H., Grasby, S. E., Stott, M. B., and Dunfield, P. F. (2014a). Humboldt's spa: microbial diversity is controlled by temperature in geothermal environments. ISME J. 8, 1166-1174. doi: 10.1038/ismej. 2013.237

Sharp, C. E., Martínez-Lorenzo, A., Brady, A. L., Grasby, S. E., and Dunfield, P. F. (2014b). Methanotrophic bacteria in warm geothermal spring sediments identified using stable-isotope probing. FEMS Microbiol. Ecol. 90, 92-102. doi: 10.1111/1574-6941.12375

Sharp, C. E., Stott, M. B., and Dunfield, P. F. (2012). Detection of autotrophic verrucomicrobial methanotrophs in a geothermal environment using stable isotope probing. Front. Microbiol. 3:303. doi: 10.3389/fmicb.2012.00303

Sipma, J., Henstra, A. M., Parshina, S. N., Lens, P. N. L., Lettinga, G., and Stams, A. J. M. (2006). Microbial CO conversions with applications in synthesis gas purification and bio-desulfurization. Crit. Rev. Biotechnol. 26, 541-547. doi: 10.1080/07388550500513974

Slepova, T. V., Rusanov, I. I., Sokolova, T. G., Bonch-Osmolovskaya, E. A., and Pimenov, N. V. (2007). Radioisotopic tracing of carbon monoxide conversion by anaerobic thermophilic prokaryotes. Microbiology 76, 523-529. doi: 10.1134/S0026261707050025

Slepova, T. V., Sokolova, T. G., Lysenko, A. M., Tourova, T. P., Kolganova, T. V., Kamzolkina, O. V., et al. (2006). Carboxydocella sporoproducens sp. nov., a novel anaerobic $\mathrm{CO}$-utilizing/ $\mathrm{H}_{2}$-producing thermophilic bacterium from a Kamchatka hot spring. Int. J. Syst. Evol. Microbiol. 56, 797-800. doi: 10.1099/ijs.0.63961-0

Sokolova, T. G., González, J. M., Kostrikina, N. A., Chernyh, N. A., Slepova, T. V., Bonch-Osmolovskaya, E. A., et al. (2004). Thermosinus carboxydivorans gen. nov., sp. nov., a new anaerobic, thermophilic, carbon-monoxide-oxidizing, hydrogenogenic bacterium from a hot pool of Yellowstone National Park. Int. J. Syst. Evol. Microbiol. 54, 2353-2359. doi: 10.1099/ijs.0.63186-0

Sokolova, T. G., Henstra, A. M., Sipma, J., Parshina, S. N., Stams, A. J. M., and Lebedinsky, A. V. (2009). Diversity and ecophysiological features of thermophilic carboxydotrophic anaerobes. FEMS Microbiol. Ecol. 68, 131-141. doi: 10.1111/j.1574-6941.2009.00663.x

Sokolova, T. G., Kostrikina, N. A., Chernyh, N. A., Kolganova, T. V., Tourova, T. P., and Bonch-Osmolovskaya, E. A. (2005). Thermincola carboxydiphila gen. nov., sp. nov., a novel anaerobic, carboxydotrophic, hydrogenogenic bacterium from a hot spring of the Lake Baikal area. Int. J. Syst. Evol. Microbiol. 55, 2069-2073. doi: 10.1099/ijs.0.63299-0

Sokolova, T. G., Kostrikina, N. A., Chernyh, N. A., Tourova, T. P., Kolganova, T. V., and Bonch-Osmolovskaya, E. A. (2002). Carboxydocella thermautotrophica gen. nov., sp. nov., a novel anaerobic, CO-utilizing thermophile from a Kamchatkan hot spring. Int. J. Syst. Evol. Microbiol. 52, 1961-1967. doi: 10.1099/ijs.0.02173-0

Sokolova, T., Hanel, J., Onyenwoke, R. U., Reysenbach, A.-L., Banta, A., Geyer R., et al. (2007). Novel chemolithotrophic, thermophilic, anaerobic bacteria Thermolithobacter ferrireducens gen. nov., sp. nov. and Thermolithobacter carboxydivorans sp. nov. Extremophiles 11, 145-157. doi: 10.1007/s00792-0060022-5

Stubner, S. (2002). Enumeration of 16S rDNA of Desulfotomaculum lineage 1 in rice field soil by real-time PCR with SybrGreen detection. J. Microbiol. Methods 50, 155-164. doi: 10.1016/S0167-7012(02)00024-6

Svetlichny, V. A., Sokolova, T. G., Gerhardt, M., Kostrikina, N. A., and Zavarzin, G. A. (1991a). Anaerobic extremely thermophilic carboxydotrophic bacteria in hydrotherms of Kuril Islands. Microb. Ecol. 21, 1-10. doi: 10.1007/BF02539140

Svetlichny, V. A., Sokolova, T. G., Gerhardt, M., Ringpfeil, M., Kostrikina, N. A., and Zavarzin, G. A. (1991b). Carboxydothermus hydrogenoformans gen. nov., sp. nov., a CO-utilizing thermophilic anaerobic bacterium from hydrothermal environments of Kunashir Island. Syst. Appl. Microbiol. 14, 254-260. doi: 10.1016/S0723-2020(11)80377-2

Techtmann, S. M., Colman, A. S., Murphy, M. B., Schackwitz, W. S., Goodwin, L. A., and Robb, F. T. (2011). Regulation of multiple carbon monoxide consumption pathways in anaerobic bacteria. Front. Microbiol. 2:147. doi: 10.3389/fmicb.2011.00147

Techtmann, S. M., Colman, A. S., and Robb, F. T. (2009). 'That which does not kill us only makes us stronger' the role of carbon monoxide in thermophilic microbial consortia. Environ. Microbiol. 11, 1027-1037. doi: 10.1111/j.14622920.2009.01865.x

Uffen, R. L. (1981). Metabolism of carbon monoxide. Enzyme Microb. Technol. 3, 197-206. doi: 10.1016/0141-0229(81)90086-7

Voordouw, G. (2002). Carbon monoxide cycling by Desulfovibrio vulgaris Hildenborough. J. Bacteriol. 184, 5903-5911. doi: 10.1128/JB.184.21.5903-5911. 2002

Wächtershäuser, G. (2006). From volcanic origins of chemoautotrophic life to Bacteria, Archaea and Eukarya. Philos. Trans. R. Soc. Lond. B Biol. Sci. 361, 1787-1808. doi: 10.1098/rstb.2006.1904

Conflict of Interest Statement: The authors declare that the research was conducted in the absence of any commercial or financial relationships that could be construed as a potential conflict of interest.

Copyright (C) 2015 Brady, Sharp, Grasby and Dunfield. This is an open-access article distributed under the terms of the Creative Commons Attribution License (CC BY). The use, distribution or reproduction in other forums is permitted, provided the original author(s) or licensor are credited and that the original publication in this journal is cited, in accordance with accepted academic practice. No use, distribution or reproduction is permitted which does not comply with these terms. 